\title{
No action without talk? UN peacekeeping, discourse, and institutional self-legitimation
}

\author{
Sarah von Billerbeck* \\ Department of Politics and International Relations, University of Reading, UK \\ ${ }^{\star}$ Corresponding author. Email: s.b.k.vonbillerbeck@reading.ac.uk
}

(Received 24 October 2018; revised 25 February 2020; accepted 25 February 2020; first published online 24 March 2020)

\begin{abstract}
In this article, I argue that much of the discourse observable within the UN constitutes neither unnecessary and unproductive 'talk' nor efforts to convince outside audiences of its legitimacy, but actually a form of institutional self-legitimation that is key to its ability to function. Using the case of the UN's Department of Peacekeeping Operations (DPKO), I show that because the organisation has a multifaceted organisational identity, it faces situations where it is forced to choose between multiple but equally appropriate courses of action, and it uses self-legitimation alongside other mechanisms to overcome these tensions. I specify three sets of circumstances in which this occurs, showing how DPKO uses discourse that simplifies and exceptionalises in a bid to reconcile or downplay these contradictions and reassert a cohesive and legitimate organisational identity internally. This simplification and exceptionalisation in turn serve an enabling function, allowing DPKO to continue operating in conditions of complexity by decreasing risk aversion and instilling a deep sense of professional loyalty in staff. At the same time, such discursive processes are costly and may entrench inefficient practices, rendering the effects of self-legitimising discourse paradoxical: they may enable action, but they reduce the efficiency and effectiveness of that action.
\end{abstract}

Keywords: United Nations; Legitimacy; Self-Legitimation; Discourse; Peacekeeping

\section{Introduction}

The UN is frequently derided for being an unwieldy and ineffective bureaucracy. Some of this criticism relates to the tendency of member states to engage in lengthy negotiations and debates, but some also derives from what appear to be laborious internal discussions and seemingly unproductive discursive activities within the Secretariat. By spending so much time talking indeed talking to itself - the UN spends less time doing, and thus fails to deliver on its stated objectives or to do so quickly and cost-effectively.

In this article, I argue that such assessments suffer from two shortcomings. First, they neglect the possibility that this internal 'talk' in the UN serves a specific and crucial function within the organisation, namely a legitimising function. Indeed, numerous studies show how institutions of global governance use discourse to generate legitimacy for themselves and their actions by communicating and projecting their relevance, effectiveness, and appropriateness. ${ }^{1}$ Second, these assessments fail to take into account the fact that at least some of the discourse in these organisations is internally rather than externally directed. The scholarship that has examined discourse as

\footnotetext{
${ }^{1}$ See Jens Steffek, 'The legitimation of international governance: A discourse approach', European Journal of International Relations, 9:2 (June 2003), pp. 249-75; Jennifer Gronau and Henning Schmidtke, 'The quest for legitimacy in world politics international institutions' legitimation strategies', Review of International Studies, 42 (2016), pp. 535-57; Dominik Zaum (ed.), Legitimating International Organizations (Oxford: Oxford University Press, 2013).

(C) British International Studies Association 2020. This is an Open Access article, distributed under the terms of the Creative Commons Attribution licence (http://creativecommons.org/licenses/by/4.0/), which permits unrestricted re-use, distribution, and reproduction in any medium, provided the original work is properly cited.
} 
a legitimation tool in global governance has focused on the views of external constituencies, such as member states, donors, or beneficiaries. This, however, leaves out the views of the staff of these organisations themselves, suggesting that they either feel no need to view themselves as legitimate or, if they do, never question their own legitimacy.

In this article, I argue that much of the discourse observable within the UN constitutes not unnecessary and unproductive 'bureaucratic chatter', but actually a form of institutional selflegitimation that is key to its ability to function. More specifically, because the UN has a multifaceted and fragmented organisational identity, it frequently faces situations where it is forced to choose between two or more equally valid courses of action. ${ }^{2}$ Where this is the case, the UN may rely on hierarchy, where senior officials dictate which courses of action are followed (often at the behest of member states); self-interest, where staff seeking to maximise personal advancement or departmental visibility lobby for particular actions; or self-legitimation, where staff use discourse to reconcile, overcome, or downplay these contradictions by portraying them, at least rhetorically, as appropriate. While it is likely that a combination of these mechanisms will be at work where trade-offs and dilemmas exist, this article focuses on the third of these.

More specifically, using a case study of the UN Department of Peacekeeping Operations, ${ }^{3}$ I demonstrate how the UN uses discourse that simplifies and exceptionalises in order to portray itself and its behaviour as non-contradictory, coherent, appropriate, and good. Importantly, this discourse is directed inwards, not at external audiences, but at UN staff themselves, who need to feel reassured that they are behaving appropriately for their organisational identity when compelled to choose between conflicting obligations.

This discourse in turn serves an enabling function, allowing UN staff to continue operating in conditions of complexity by, first, decreasing risk aversion and, second, instilling a deep sense of professional loyalty in them. In this regard, self-legitimising discourse helps to create a unified organisational narrative in the face of trade-offs and dilemmas, without which staff would find it difficult to act at all. In short, the UN should not be characterised as 'all talk and no action', but rather 'no action without talk'. At the same time, the effects of self-legitimising discourse are not entirely positive. Discursive practices are time-consuming and costly and can lead to inaccurate or insufficient self-assessment, and thus may impede the efficiency and effectiveness of any action that they enable. In this sense, self-legitimation is paradoxical: it may be crucial to the work of the UN, but it also renders that work less efficient.

I proceed as follows. The first part of the article is theoretical. First, I introduce the concept of self-legitimation, situating it within scholarship on legitimacy and legitimation from International Relations (IR), organisation studies, and sociology. Second, I apply it to UN peace operations, explaining how this flagship activity of the UN showcases the UN's multiple organisational identities and the resulting dilemmas and trade-offs faced by staff. Third, I discuss how selflegitimising discourse is one of the ways that staff deal with such complexity: through the creation of narratives that simplify and exceptionalise, they portray their actions as appropriate and irreproachable. My focus is on the individual self-identifications of DPKO staff; however, because these are professional identities, are the product of social interactions with other staff in the context of DPKO, and are widely shared among most staff, they can be viewed as a collective identity that is representative of an overall organisational identity. ${ }^{4}$

The second part of the article is empirical and presents findings and analysis from in-depth qualitative interviews of DPKO staff. First, after outlining the methods used for this study, I distinguish three sets of circumstances in which DPKO self-legitimises. Second, I explore the content of the UN's legitimising discourse, identifying four themes that serve to simplify conflicting

\footnotetext{
${ }^{2}$ Sarah von Billerbeck, 'UN peace operations and conflicting legitimacies', Journal of Intervention and Statebuilding, 11:3 (2017), pp. 286-305.

${ }^{3}$ DPKO was renamed the Department of Peace Operations (DPO) in January 2019.

${ }^{4}$ Note that for simplicity, I sometimes refer to the collective staff of DPKO simply as 'DPKO'.
} 
obligations and to exceptionalise DPKO staff, portraying them as unique and morally superior. Finally, I examine the repercussions of this discourse, including both how it enables action but also reduces efficiency, rendering the effects staff members' discourse paradoxical. The final section concludes, offering reflections on how self-legitimation functions in the UN more broadly and in other international organisations.

\section{Legitimacy, legitimation, and discourse}

Most definitions of legitimacy focus on the possession and use of power in the relationship between rulers and ruled. Where powerful actors wield their authority in accordance with a set of shared, socially embedded norms and values, they are considered legitimate by those subject to it, and the latter are more likely to comply with authority voluntarily, rather than being forced to through coercion or tempted to through inducements. ${ }^{5}$ Legitimacy, in this way, is considered to enhance the effectiveness of those in power because obedience and acquiescence are more certain and less costly. As Inis L. Claude has pointed out, '[l]egitimacy ... makes all rulers more effective more secure in the possession of power and more successful in its exercise. ${ }^{6}$

This is particularly true in the case of international organisations like the UN, which usually do not possess the means to elicit compliance through coercion or inducements. ${ }^{7}$ Indeed, Mark C. Suchman describes legitimacy as 'an operational resource that organizations ... employ in pursuit of their goals'. The link between legitimacy and effectiveness has been a particular focus of studies of peacekeeping. ${ }^{9}$ If an operation is deemed legitimate - that is, if its actions and objectives are considered appropriate according to shared norms and principles - host country populations that are subject to the operation will comply with it, donors that fund it will continue to provide resources, and states that authorise it will renew its mandate.

For this reason, peace operations, as well as international organisations more generally, make particular efforts to cultivate legitimacy for themselves - that is, to engage in legitimation. In contrast to legitimacy, which can be conceived of as perceived compliance with norms and values present in the organisational environment, legitimation entails a set of practices aimed at asserting and demonstrating that compliance; in short, legitimacy is the goal, legitimation is the way to get there.

These legitimation efforts tend to be discursive in nature. As Jens Steffek argues, legitimation usually occurs through 'public discourse' and a 'communicative process' through which the party seeking legitimacy "giv[es] reasons" for why those subject to it should comply. ${ }^{10}$ It involves demonstrating alignment with the rules and principles of a particular social setting and demonstrating the appropriateness of one's role and behaviour in that setting. Peter L. Berger and Thomas Luckman also describe legitimation as a process of 'explanation', ${ }^{11}$ and Theo Van Leeuwen asserts that '[l]anguage is without doubt the most important vehicle for [legitimation]

\footnotetext{
${ }^{5}$ Steffek, 'Legitimation of international governance', p. 254.

${ }^{6}$ Inis L. Claude, Jr, 'Collective legitimation as a political function of the United Nations', International Organization, 20:3 (1966), pp. 367-79 (p. 368).

${ }^{7}$ Ian Hurd, After Anarchy: Legitimacy and Power in the United Nations Security Council (Princeton: Princeton University Press, 2007).

${ }^{8}$ Mark C. Suchman, 'Managing legitimacy: Strategic and institutional approaches', Academy of Management Review, 20:3 (1995), pp. 571-610 (p. 576), emphasis in original.

${ }^{9}$ See, for example, Jeni Whalan, How Peace Operations Work: Power, Legitimacy, and Effectiveness (Oxford: Oxford University Press, 2013); Thomas Risse, 'No success without legitimacy! A comment on military intervention', Global Policy (18 June 2014).

${ }^{10}$ Jens Steffek, 'Discursive legitimation in environmental governance', Forest Policy and Economics, 11 (2009), pp. 313-18 (p. 315).

${ }^{11}$ Peter L. Berger and Thomas Luckman, The Social Construction of Reality: A Treatise in the Sociology of Knowledge (New York: Penguin, 1966), p. 112.
} 
attempts. ${ }^{12}$ In short, through language and other media, actors are able to delineate the social environment, specify the identity and role of actors within it, and make claims about how their behaviour is rational, appropriate, and legitimate in that environment. ${ }^{13}$

\section{Self-legitimacy and self-legitimation}

These definitions are only partly useful in thinking about self-legitimation. Because they focus on external perceptions of legitimacy and externally directed legitimation practices, they fail to acknowledge that without an internal sense of legitimacy, organisations like the UN may find it difficult to act at all because they would lack a clear sense that they are the appropriate actor to take on particular tasks and a sense that their actions are cohesive and appropriate. This would, indeed, make it difficult or even impossible to make such claims to outside audiences. In this way, self-legitimation differs from 'traditional' definitions of legitimation in that the binary relationship between actors is no longer relevant. Instead, self-legitimacy is concerned with an actor's own perceptions of its appropriateness, and self-legitimation thus entails an endogenous process that focuses on the (re)construction and (re)affirmation of an identity that can be considered appropriate and aligned with norms and values present in a particular setting. ${ }^{14}$ In short, self-legitimation is a process by which actors reassure themselves that they are legitimate and that they are acting in ways appropriate to their identity in a given social or organisational environment.

Notably, actors' concern with internal legitimacy and their efforts to reaffirm, for themselves, a cohesive and appropriate sense of identity has received relatively little dedicated study. This is despite the fact that scholars from a variety of fields, including IR, sociology, and organisational studies, have remarked upon the importance of self-perceptions of legitimacy and a clear sense of institutional identity for organisations to be able to effectively fulfill their mandates. John W. Meyer and Brian Rowan note that organisations that comply with 'collectively valued purposes in a proper and adequate manner' are able to 'increase their legitimacy' and thus be more successful. ${ }^{15}$ Similarly, Mats Alvesson and Hugh Willmott assert that a cohesive organisational identity that staff consider 'appropriate, desirable and valued' can produce 'a degree of existential continuity and security' for them, while its absence can generate 'tensions and the possibility of breakdown', thus leading to ineffectiveness. ${ }^{16}$ Andrea Oelsner, similarly, stresses that a strong and cohesive sense of identity is indispensable for organisational effectiveness, ${ }^{17}$ and Rodney Barker, likewise, argues that, in addition to its external forms, 'legitimation is an activity which serves to confirm the identity of the legitimator'. ${ }^{18}$ All of these comments point to a

\footnotetext{
${ }^{12}$ Theo Van Leeuwen, 'Legitimation in discourse and communication', Discourse and Communication, 1:1 (2007), pp. 91112 (p. 91). See also Rodney Barker, Legitimating Identities: The Self-Presentations of Rules and Subjects (Cambridge: Cambridge University Press, 2001), and Jeffrey Pfeffer, Power in Organizations (Marshall, MA: Pitman, 1981).

${ }^{13}$ Though beyond the scope of this article, which focuses on language and narratives, discursive activities can also extend to visual, material, and performative acts, including symbols, rituals, and events. See Suchman, 'Managing legitimacy', p. 586, and Barker, Legitimating Identities, pp. 41, 51.

${ }^{14}$ Ben Bradford and Paul Quinton, 'Self-legitimacy, police culture and support for democratic policing in an English constabulary', British Journal of Criminology, 54 (2014), pp. 1023-46 (p. 1027); Barker, Legitimating Identities, p. 112.

${ }^{15}$ John W. Meyer and Brian Rowan, 'Institutionalized organizations: Formal structure as myth and ceremony', American Journal of Sociology, 83:2 (1977), pp. 340-63 (pp. 349, 340).

${ }^{16}$ Mats Alvesson and Hugh Willmott, 'Identity regulation as organizational control: Producing the appropriate individual', Journal of Management Studies, 39:5 (2002), pp. 620-44 (pp. 625-6).

${ }^{17}$ Andrea Oelsner, 'The institutional identity of regional organizations, or Mercosur's identity crisis', International Studies Quarterly, 57 (2013), pp. 115-27 (p. 117).

${ }^{18}$ Barker, Legitimating Identities, p. 112.
} 
utilitarian view of self-legitimation in organisations: not only does it provide a kind of psychological or ontological security for organisations, but it is also perceived to render them more effective. $^{19}$

This process is particularly important in organisations that have fragmented or contradictory identities. As I argue elsewhere, for organisations with multiple identities that each have their own set of normatively appropriate behaviours and normatively acceptable goals, it becomes difficult to construct and reaffirm a cohesive sense of institutional legitimacy because in reaffirming one identity, they may contradict another. ${ }^{20}$ In other words, organisations with multifaceted identities may sometimes face conflicting or mutually exclusive 'appropriatenesses', and therefore will be forced to 'violate' what is appropriate to one side of its identity in order to comply with what is appropriate to another. This in turn may counteract any gains in terms of effectiveness described above, because the organisation will lack coherence and clear purposes. As a result, it is precisely such organisations that have the greatest need to engage in self-legitimation, as their legitimacy will be less secure than that of an organisation with a single, clear identity and sense of mission.

Few organisations capture this level of fragmentation more than the UN's Department of Peacekeeping Operations (DPKO). I highlight two sources of fragmentation. First, the UN fills both normative and operational functions in its peacekeeping operations. ${ }^{21}$ On the one hand, it is the global leader in setting standards for appropriate behaviour in the international system relating to governance, human rights, and justice in conflict and postconflict situations. On the other hand, it operates 13 peacekeeping operations with nearly 100,000 personnel and engages in combat, humanitarian relief, institutional reform, and capacity building. ${ }^{22}$ These different normative and operational identities can entail mutually exclusive obligations and dictate appropriate behaviours that conflict with one another. For example, normative imperatives related to inclusive processes, consensus requirements, and transparency and operational imperatives related to the timely and cost-effective delivery of results often clash in practice. Similarly, the inclusion of spoilers or those with records of human rights violations in peace processes may be critical to securing and sustaining peace but may also be detrimental to the cause of justice and to the UN's own dedication to the promotion of human rights. ${ }^{23}$

Second, DPKO is simultaneously an instrument of UN member states tasked with implementing Security Council peacekeeping mandates and an independent body of experts, who have specialised knowledge, skills, and often lengthy experience relating to the design and implementation of peacekeeping. ${ }^{24}$ DPKO staff understand and accept that, according to the Charter, their role entails the execution of decisions by the Security Council and other member states, but because

\footnotetext{
${ }^{19}$ The idea of ontological security was first developed by psychologists who asserted that individuals require a stable sense of self. This idea was subsequently adopted into organisational studies and IR, which hold that organisations and states also require cohesive identities. See Anthony Giddens, Modernity and Self-Identity: Self and Society in the Late Modern Age (Stanford, CA: Stanford University Press, 1991); Filip Ejdus, 'Critical situations, fundamental questions and ontological insecurity in world politics', Journal of International Relations and Development (2017); and Jennifer Mitzen, 'Ontological security in world politics: State identity and the security dilemma', European Journal of International Relations, 12:3 (2006), pp. 341-70.

${ }^{20}$ Sarah von Billerbeck, “Mirror, mirror, on the wall”: Self-legitimation by international organizations', International Studies Quarterly, Online First (2019).

${ }^{21}$ Ibid.

${ }^{22}$ United Nations Peacekeeping, 'Global Peacekeeping Data (as of 31 January 2020)', available at: \{https://peacekeeping.un. org/en/data\} accessed 19 February 2020.

${ }^{23}$ Roland Paris and Timothy D. Sisk, 'Managing Contradictions: The Inherent Dilemmas of Postwar Statebuilding', Research Partnership on Postwar Statebuilding, International Peace Academy (November 2007); Stephen Stedman, 'Spoiler problems in peace processes', International Security, 22:2 (1997), pp. 5-53; see also Whalan, Peace Operations, pp. 31-2.

${ }^{24}$ von Billerbeck, “'Mirror, mirror"'; Inis L. Claude, 'Peace and security: Prospective roles for the two united nations', Global Governance, 2:3 (1996), pp. 289-98.
} 
they self-identify as experts in peacekeeping, they also want to demonstrate their expertise, utilise their experience, and follow courses of action they deem appropriate based upon their own analysis. ${ }^{25}$ However, what staff think is most appropriate and what member states consider the best course of action may not align, thus again creating situations where DPKO staff face contradictory, if equally valid, obligations.

As these two divisions show, DPKO staff face an incoherent and contradictory institutional identity, and these different facets of its identity can prescribe conflicting objectives and can entail conflicting sets of appropriate behaviour. These conflicts, in turn, make it harder for DPKO staff to maintain a sense of their own legitimacy: if behaviour appropriate to one side of their identity contradicts behaviour appropriate to another, staff are unlikely to view themselves as legitimate and their work as right or valid. ${ }^{26}$ As noted above, this can engender tension or breakdown in organisational settings and can reduce effectiveness. Accordingly, DPKO staff engage in self-legitimation in a bid to reconcile such contradictions, reassert a cohesive institutional identity, show their alignment with shared norms and values, and thus demonstrate their appropriateness and legitimacy.

\section{The discourse of self-legitimation: Simplification and exceptionalisation}

Efforts to generate such self-perceptions of legitimacy, like with external legitimation, come largely through discourse. As mentioned, discourse uses language and communication to construct and frame the social world, to specify the identity and role of particular actors within it, and to define appropriate, acceptable, and rational behaviour. ${ }^{27}$ In the case of UN peacekeeping, some of these discursive practices may of course be externally visible, but they are also aimed at an internal audience, sometimes exclusively, in a bid to reassure staff that they are acting in accordance with particular socially embedded norms and values that are appropriate to their organisational identity. ${ }^{28}$ This self-legitimising discourse achieves these aims through simplification and exceptionalisation. Both of these enable DPKO staff to construct a version of reality in which the contradictions they face are minimised or ignored and their actions are necessarily good, and one in which their role is distinct and clearly defined, thus reasserting a cohesive institutional identity and unambiguous legitimacy. ${ }^{29}$

First, as noted, internal perceptions of legitimacy are particularly hard to generate and maintain in organisations that face contradictory or mutually exclusive obligations and tasks. Discourse that simplifies, 'papers over', or ignores such contradictions can therefore help staff to maintain a

\footnotetext{
${ }^{25}$ United Nations, Charter of the United Nations (New York: United Nations, 1945), ch. XV; Susan Hannah Allen and Amy T. Yuen, 'The politics of peacekeeping: UN Security Council oversight across peacekeeping missions', International Studies Quarterly, 58 (2014), pp. 621-32 (p. 623); and Joel Gwyn Winckler, 'Exceeding limitations of the United Nations peacekeeping bureaucracy: Strategies of officials to influence peacekeeping activities within the United Nations mission in Liberia and the Department of Peacekeeping Operations', International Peacekeeping, 22:1 (2015), pp. $43-64$ (p. 43 ).

${ }^{26}$ von Billerbeck, "“Mirror, mirror".

${ }^{27}$ Séverine Autesserre, 'Dangerous tales: Dominant narratives on the Congo and their unintended consequences', African Affairs, 111:443 (2012), pp. 202-22; Bentley B. Allan, Scientific Cosmology and International Orders (Cambridge: Cambridge University Press, 2018), pp. 40-1; and Peter Kjær and Ove K. Pedersen, 'Translating liberalization: Neoliberalism in the Danish negotiated economy', in John L. Campbell and Ove K. Pedersen (eds), The Rise of Neoliberalism and Institutional Analysis (Princeton and Oxford: Princeton University Press, 2001).

${ }^{28}$ As mentioned above, it is important to note here that while I refer to organisational identity, I focus empirically on the individual self-identity and individual and group discursive practices of staff members. Because these are professional identities and practices (as opposed to private or personal ones) that exist within the context of DPKO, are the product of interactions between staff in the workplace, and are shared by most staff, they jointly constitute a shared organisational identity.

${ }^{29} \mathrm{I}$ do not use the term 'exception' in the sense of that most theories of exception in IR do. The latter do not address legitimacy or international organisations, but are taken up in the context of the state and securitisation, where states have the authority to decide upon exceptions to rules and laws. However, these theories do point out that exceptions are constitutive of social orders and political communities, similar to the sense in which I use the term here. See, for example, Claudia Aradau and Rens van Munster, 'Exceptionalism and the "war on terror": Criminology meets International Relations', The British Journal of Criminology, 49:5 (2009), pp. 686-701.
} 
cohesive sense of mission, purpose, and appropriateness and, by extension, to continue operating in conditions of complexity. Indeed, self-legitimising discourse should not aim to capture or explain complexity, but instead should provide an account of the multiple and conflicting tasks faced by staff that portrays them either as reconciled, coexisting, or non-existent, thus doing away with factors that are confusing or contradictory. Séverine Autesserre describes the 'power' of simplified narratives in conflict settings, ${ }^{30}$ and Mathijs van Leeuwen likewise asserts that peacebuilding actors 'need to simplify reality to be able to operate and deal with the complexity of conflict and peacebuilding. ${ }^{31}$ Bentley B. Allan notes that discourses usually 'present only a small portion of reality', ${ }^{32}$ and John Law similarly argues that organisations use various discourses which he refers to as 'modes of ordering' - to simplify and thus cope with complexity. ${ }^{33}$

While these references mostly refer to external complexity - that is, a characteristic of the operational context in which peacekeeping occurs - it applies equally to complexity that derives from within an organisation - in this case from the multiple and conflicting operational, normative, and institutional obligations entailed by the different sides of DPKO's identity. Simplifying discourse in this regard enables staff to view their identity as cohesive and unitary rather than fragmented and incoherent, and thus to maintain a sense of their own legitimacy in the face of difficult choices.

Second, discourse that portrays staff as exceptional, unique, and superior also helps to boost identity cohesion and overcome or diminish contradictions and hard choices. Exceptionalising discourse suggests that legitimacy comes from being unique and morally superior and thus 'above' operational trade-offs. Tyler Wry, Michael Lounsbury, and Mary Ann Glynn contend that 'legitimacy is more likely to be achieved when [organisation] members articulate a clear defining collective identity story that identifies the group's orienting purpose and core practices'. ${ }^{34}$ Barker concurs, arguing that internal perceptions of legitimacy relate strongly to feeling that one is 'special, marked by particular qualities, [and] set apart from other people'. ${ }^{35}$ Discourse that portrays DPKO staff in these terms, then, helps them to remain reassured of their legitimacy: even where they are forced to take actions that may contradict one side of their identity, their overall moral superiority and appropriateness remain unchanged.

In the next sections I explore the discourse of self-legitimation empirically in DPKO. After specifying my methodological approach and case selection, I first outline three sets of circumstances in which staff in DPKO self-legitimise. Second, I explore the content of their selflegitimacy, highlighting four themes that run through their discourse and that simplify or eliminate the trade-offs they face and that exceptionalise DPKO staff and portray them as above and unaffected by those trade-offs. Finally, I describe how this discourse fills both an enabling function, allowing DPKO staff to function in spite of the trade-offs they face, but how it simultaneously reduces effectiveness and efficiency, thus reversing some of the positive effects of self-legitimation.

\section{Methods and case selection}

In studying legitimacy empirically, scholars are divided over whether it should be viewed as a prescriptive or descriptive phenomenon. ${ }^{36}$ According to prescriptive conceptions, legitimacy exists

\footnotetext{
${ }^{30}$ Autesserre, 'Dangerous tales'.

${ }^{31}$ Mathijs van Leeuwen, Partners in Peace: Discourses and Practices of Civil-Society Peacebuilding (Abingdon: Routledge, 2009), p. 7.

${ }^{32}$ Allan, Scientific Cosmology, p. 42.

${ }^{33}$ John Law, Organising Modernity: Social Ordering and Social Theory (Oxford: Blackwell, 1994).

${ }^{34}$ Tyler Wry, Michael Lounsbury, and Mary Ann Glynn, 'Legitimating nascent collective identities: Coordinating cultural entrepreneurship', Organization Science, 22:2 (2011), pp. 449-63 (p. 449), emphasis in original.

${ }^{35}$ Barker, Legitimating Identities, p. 35.

${ }^{36}$ See Steffek, 'Legitimation of international governance', p. 253. These different types are sometimes referred to as objective and subjective or normative and empirical. See Sarah von Billerbeck and Birte Julia Gippert, 'Introducing legitimacy in
} 
when an authority meets certain external, objective standards. According to descriptive conceptions, it exists when those subject to that authority perceive it to exist. In this article, I adopt the latter conception since I am concerned with DPKO's perceptions of its own legitimacy. Such perceptions are, of course, difficult to measure, and measurement relies heavily on the subjective, expressed views of staff within DPKO. Accordingly, my analysis is based upon in-depth interviews in order to empirically study how UN staff create and assess their own legitimacy.

My focus is, as mentioned, on DPKO. There are several reasons for this choice. First, the UN is a vast and variegated organisation, and a study of self-legitimation in the entire organisation would be unfeasible. Second and more importantly, DPKO has a highly fragmented organisational identity, as mentioned above, and thus it regularly faces conflicting obligations and objectives. As described, DPKO is both a normative and an operational actor; it is also both a body of skilled practitioners with its own preferences and outlooks and a degree of autonomy, as well as an instrument established, tasked, and funded by member states that is obliged to do as they instruct. While in this sense, DPKO constitutes a hard case, ${ }^{37}$ it also means that there will be multiple instances where self-legitimising discourse can be observed since self-legitimation is more likely to occur in organisations with multiple and conflicting identities. The examination of a hard case, of course, reduces generalisability, but is useful in identifying the strongest means through which and widest range of conditions under which self-legitimation occurs. ${ }^{38}$ Finally, DPKO is a part of the UN that is accessible to researchers, and thus practices of self-legitimation are both observable and ascertainable through interviews.

I undertook four rounds of fieldwork in New York, Geneva, and Berlin, conducting 37 in-depth semi-structured interviews with current and former staff of DPKO and other divisions of the UN that collaborate operationally with DPKO. These were conducted between January 2017 and February 2018. I used a purposeful sampling technique to recruit interviewees, seeking a range of levels of seniority, function, and duration of tenure in DPKO in order to ensure that the views expressed were broadly representative of the population of DPKO as a whole. All interviewees were civilian Secretariat staff, not national representatives seconded to the UN; most have held posts both in headquarters and in peacekeeping missions in the field.

I used the concept of saturation in drawing conclusions. Data saturation in qualitative research is reached when a study can be replicated, when no new themes can be identified, and when further data collection and coding are not feasible. ${ }^{39}$ When this point is reached will vary by project; however, in this case, the emergence of patterns and common themes was apparent from early on, and there was remarkably little variation between interviewees. My purposeful recruitment of a diverse group of interviewees within DPKO provided protection against biased data by ensuring that I did not only record the views of individuals with similar profiles who might therefore share the same perspective. ${ }^{40}$

\section{Self-legitimation in UN peacekeeping: Three sets of circumstances}

As described, DPKO faces a multifaceted and contradictory institutional identity that confronts staff with trade-offs, dilemmas, and difficult choices about how to behave appropriately. This

conflict: Concepts, practices, challenges', Journal of Intervention and Statebuilding, 11:3 (2017), pp. 286-305, and Gronau and Schmidtke, 'The quest for legitimacy'.

${ }^{37}$ Jason Seawright and John Gerring, 'Case selection techniques in case study research: A menu of qualitative and quantitative options', Political Research Quarterly, 61:2 (2008), pp. 294-308.

${ }^{38} \mathrm{I}$ take up the application of my findings to other organisations, including both other parts of the UN and other international organisations, in the conclusion.

${ }^{39}$ Patricia I. Fusch and Lawrence R. Ness, 'Are we there yet? Data saturation in qualitative research', The Qualitative Report, 20:9 (2015), pp. 1408-16 (p. 1409).

${ }^{40}$ H. Russell Bernard, Social Research Methods: Qualitative and Quantitative Approaches (2 ${ }^{\text {nd }}$ edn, Thousand Oaks, CA: Sage, 2012). 
raises doubts for staff about their own legitimacy and the legitimacy of their work, and accordingly they use self-legitimising discourse in order to assuage these doubts. There are three sets of circumstances in which this occurs: where normative and operational imperatives clash, where the peacekeeping agenda is aligned only with narrow member state interests, and where results are weak or peacekeeping is beset by scandals. ${ }^{41}$

First, staff described a variety of situations in peacekeeping in which their normative and operational responsibilities conflict, forcing them to 'choose between' different obligations. For example, one senior peacekeeping official noted that missions are often confronted both with host states that insist that the UN respect their sovereignty and territorial integrity and with minority groups that insist upon their right to self-determination, calling this 'the big dilemma' for peacekeeping personnel. ${ }^{42}$ Similarly, in interacting with host country populations and governments, staff grapple with dual imperatives towards local ownership and support for the host government and towards efficiently delivering outcomes. ${ }^{43}$ One noted that 'on one hand, you want to get things done. People need services, especially for countries emerging from horrific civil war and where everything's been destroyed ... But, at the same time, very quickly the disenchantment [with the UN] sets in', and if the UN does '[too] much of the heavy lifting, you then undermine the legitimacy of that government because it's not seen to exercise authority'. ${ }^{44}$

Other staff members pointed to dilemmas surrounding the protection of civilians and promotion of human rights in peacekeeping. One official noted, for example, that the UN is expected to uphold the highest standards of human rights when it intervenes, but, when faced with the reality of securing peace among conflict parties, queried, 'how do you, in this context, compromise on values that are in the UN Charter ...? ${ }^{45}$ Another described how peacekeeping staff are expected to avoid dealmaking 'with those with bad human rights records, but [also] have to negotiate to get humanitarian results', adding that this is particularly difficult where the party committing abuses is the host country government, which missions are usually mandated to support. ${ }^{46}$ Another noted that there is 'quite a lot of tension over ... the UN's normative commitment to human rights that precedes or even overrides all Security Council mandates ... and in fact you have a Security Council resolution for protection of civilians that says, "This is an overarching and overriding responsibility," and yet you have then the realities on the ground. ${ }^{47}$ This official stressed that peacekeeping staff perceive of such situations as a 'challenge to our normative frameworks'. In other words, staff members' own perceptions of their own legitimacy were thrown into question when faced with such dilemmas between the normative and the operational - dilemmas that one former official called 'unsquareable circles'. ${ }^{48}$

Second, DPKO staff expressed concerns over their internal legitimacy when they felt that the peacekeeping agenda was entirely set by member states, without their input. As international civil servants, peacekeeping staff view themselves as independent, impartial experts in the design and practice of peacekeeping, and they dislike when member states fail to take their perspectives into account and instead make policy only on the basis of narrow national interests. One DPKO official explained that ' $[\mathrm{w}] \mathrm{e}$ 're the UN, we're not from a member state, and we need to maintain a distance from the national. ${ }^{39}$ Several others echoed this, specifying that they view it as their explicit duty - and indeed moral responsibility - to respond to, push back against, and challenge

\footnotetext{
${ }^{41}$ von Billerbeck, "'Mirror, mirror".

${ }^{42}$ Interview with former senior DPKO official, Geneva, January 2017.

${ }^{43}$ Sarah von Billerbeck, Whose Peace? Local Ownership and United Nations Peacekeeping (Oxford: Oxford University Press, 2016).

${ }^{44}$ Interview with former senior DPKO official, Geneva, January 2017.

${ }^{45}$ Interview with UN official, Geneva, January 2017.

${ }^{46}$ Interview with senior DPKO official, Geneva, February 2017.

${ }^{47}$ Interview with DPKO official, New York, February 2017.

${ }^{48}$ Interview with former senior DPKO official, Geneva, February 2017.

${ }^{49}$ Interview with DPKO official, New York, February 2017
} 
member states, deploying their expertise to try to influence policy towards more impartial, multilateral, and non-interested-based outcomes. Several officials expressed strong resentment at being 'micromanaged by member states', 50 and one official declared that '[w]e have a duty to stand up to the P5', describing how doing so correlated directly with her sense of the legitimacy of her role. ${ }^{51}$ Another concurred, noting that the ability of staff to use their expertise and experience in shaping policy is 'all about legitimacy. ${ }^{52}$ In this way, staff portray what they view as their duty to engage in principled opposition to member states in moral terms and, as such, part of their normative identity as international civil servants.

Of course, staff acknowledged the fact that, as members of the UN Secretariat, their role officially is to implement the decisions of the Security Council. They equally recognised that member states often seek the advice of Secretariat personnel on questions of peacekeeping, mission design, implementation, and drawdown, and that the relationship is not purely adversarial. ${ }^{53}$ Yet in situations where major powers, particularly the P5, had specific interests, they felt that any expertise and analysis they provided was sidelined and national interests took over. This in turn meant that a key element of their institutional identity was threatened, thus resulting in a need to self-legitimise.

Third, DPKO staff expressed particular legitimacy concerns and hence a need to self-legitimise when they felt that operations were not going well, including minimal demonstrable results, a reversion to fighting in the host country, or allegations of sexual exploitation and abuse (SEA) or other criminal acts by UN personnel. One official noted that his sense of the legitimacy of his role depended on 'seeing results and being part of something that's bigger than you are, 54 and a senior manager noted that staff under his supervision are most motivated, convinced of their utility and correctness, and satisfied professionally when they 'see the impact of their work' ${ }^{55}$ When this is not the case, staff question their legitimacy. One argued that, '[y]ou come as the international community, with flags, logos, vehicles, and you think you're going to make a difference ... But then you encounter challenging circumstances ... In these circumstances, how can you keep that sense of purpose? ${ }^{56}$ Another argued that the enormity of the ultimate goals of peacekeeping means that it is rare that staff feel things are going particularly well or that their work is having much impact, and 'so the sense has been [that] legitimacy is going to have to be derived from different things because [host] state transformation is impossible. ${ }^{57}$ Finally, several stated that where there were instances of SEA perpetrated by UN troops or other scandals involving misconduct by staff, their sense of legitimacy suffered particularly badly. One described that when abuses took place 'under the blue flag ... our own legitimacy [was] at risk' - not just in the eyes of the broader international community, but internally as well. ${ }^{58}$ In other words, where events occur that contradict self-perceptions of their identity or that entail behaviour inappropriate to that identity, DPKO staff must find alternate sources of legitimacy, and thus they turn to self-legitimation.

Importantly, where staff stood on the answers to the difficult choices they face in peacekeeping did not affect their need to self-legitimise. Indeed, disagreement among staff may actually heighten the need to self-legitimise because the awareness of strong divisions within DPKO again threatens cohesion and appropriateness. As a result, even if staff took different views of the right course of action in a given situation, or disagreed about which of two conflicting

\footnotetext{
${ }^{50}$ Interview with senior UN official, Geneva, January 2017.

${ }^{51}$ Interview with DPKO official, New York, February 2017.

${ }^{52}$ Interview with DPKO official, New York, February 2017, emphasis in original.

${ }^{53}$ Interview with senior DPKO officials, Geneva and New York, February 2017.

${ }^{54}$ Interview with DPKO official, New York, February 2017.

${ }^{55}$ Interview with senior UN official, Geneva, January 2017.

${ }^{56}$ Interview with DPKO official, New York, February 2017.

${ }^{57}$ Interview with DPKO official, New York, February 2017.

${ }^{58}$ Interview with former senior DPKO official, Geneva, January 2017.
} 
obligations should be prioritised, their need to self-legitimise was the same and the content of their discourse, as I discuss in the next section, was remarkably uniform.

\section{Self-legitimising discourse: Four themes}

In order to cope with dilemmas and conflicting obligations, the inability to influence policy, and weak results, failures, and scandals, staff engage in self-legitimation. As discussed above, they use discourse that simplifies the trade-offs and dilemmas that DPKO staff face and that asserts that they are exceptional and superior in the international system. This simplification and exceptionalisation in turn enable them to construct and continuously reaffirm a coherent institutional identity and thus retain a sense of their own appropriateness and legitimacy. This discourse focuses on four themes: the normative content of peacekeeping and the overarching values of the UN; the multilateral nature of peacekeeping; the specialised nature of peacekeeping work and the unique skills and expertise of DPKO staff; and redefinitions of success that focus on vague normative criteria, rather than on the delivery of concrete outputs.

First, staff use discourse that emphasises the normative content of peacekeeping objectives and the correctness of the UN as an organisation at the broadest level. This discourse disregards the operational and ethical difficulties encountered in the practice of peacekeeping, and focuses instead on the moral incontestability of the pursuit of peace and the universality of the UN's overarching values. For example, one former staff member described the work of peacekeeping as 'self-evidently right', adding that, 'for that reason you didn't need to justify it, you didn't even need to be particularly good at it, you didn't need to have any new ideas, you didn't need to subject yourself to any scrutiny'. ${ }^{59}$ This does not mean that staff do not acknowledge or worry about the trade-offs they face - on the contrary, they were keenly aware of these dilemmas. ${ }^{60}$ But their awareness and acceptance of them often blurred into disregard and avoidance. Staff frequently told themselves that because they represented something bigger, something morally correct, and something unquestionably good - working for international peace and security, the protection of civilians, the promotion of human rights, and the facilitation of political representation and citizen participation ${ }^{61}$ - they were able to 'assum[e] that [their work] was legitimate, and that the ends ... justified the means'. ${ }^{2}$ Several others reiterated this, calling peacekeeping 'selfevidently legitimate work'. ${ }^{63}$ In other words, staff use discourse that simplifies the goals of peacekeeping, thus ignoring the complexities and difficult choices they are sometimes forced to make when actually implementing those goals. In addition, these broad goals are considered morally unassailable and beyond reproach, and therefore the fact that DPKO staff work for them makes them exceptional and set apart from other actors in the international system.

Beyond the normative content of peacekeeping itself, DPKO staff also appealed to the overarching values of the Charter. One official declared that the injunction 'to save succeeding generations from the scourge of war' was the Charter's 'most precious sentence'. ${ }^{64}$ And while he admitted that in the daily work of peacekeeping, as a matter of practicality, one must translate such aspirational goals into more bite-sized, implementable ones, he did maintain that ' $\mathrm{t}$ ] he reason that you get up in the morning is because you tell yourself you're going to deliver peace, security, and participatory development. ${ }^{36}$ Another agreed, declaring that the Charter is 'the most beautiful prose ever written in the English language' and 'it's very difficult to read that

\footnotetext{
${ }^{59}$ Interview with former senior DPKO official, Geneva, February 2017.

${ }^{60}$ Interviews with DPKO officials, New York, February 2017.

${ }^{61}$ United Nations, 'What is Peacekeeping', available at: $\{$ https://peacekeeping.un.org/en/what-is-peacekeeping $\}$ accessed 25 February 2020.

${ }^{62}$ Interview with former senior DPKO official, Geneva, February 2017.

${ }^{63}$ Interview with former senior DPKO official, Geneva, February 2017.

${ }^{64}$ Interview with UN official, New York, February 2017.

${ }^{65}$ Interview with UN official, New York, February 2017.
} 
and not be moved' ${ }^{66}$ Others also concurred, with one noting that '[the Charter] creates the overall legitimacy [of] why you have a peacekeeping mission ... I really do believe that. ${ }^{67}$ In this way, appealing to the values of the Charter enables staff to both simplify what they do into clear and unassailable objectives and reaffirm that what they are doing is right and correct, regardless of any trade-offs and dilemmas they face in practice.

Moreover, staff further buttress their own legitimacy by telling themselves that these goals and values are universally shared. In peace operations, it is not uncommon for UN staff to find themselves operating among beneficiaries and stakeholders who may not agree with their mandated tasks and goals. Yet as one staff member described, 'I believe [in] a set of beliefs we all share that is core, irrespective of culture ... [which makes] me feel less conflicted about some of the actions we [are] doing. ${ }^{68}$ Another asserted that '[w]e all in a way are good intrinsically, without questioning the applicability, feasibility, and even desirability of our work in some of the societies we're working in. ${ }^{69}$ Another noted that because staff were, as he described it, 'self-referentially legitimate', they could avoid scrutinising their behavior when it was contradictory or ethically questionable, for example, when they 'us[ed] colossally undemocratic means to prepare a democratic society. ${ }^{70}$ Another noted that while peacekeeping has evolved over time, 'there are certain things and certain rules that are immutable ${ }^{, 71}$ - that is, values and processes that DPKO staff consider universally acknowledged as the 'right' way to do things and therefore not up for discussion or negotiation. In this way, UN staff appeal to what they consider undisputed and undisputable moral standards in an attempt to 'convince [them] selves' that they are behaving appropriately. ${ }^{72}$ Put differently, their discourse focuses on what the UN represents in the broadest sense - its lofty goals of creating and maintaining international peace and security and of creating a world characterised by equality and tolerance - what one former staff member called 'the idea of the UN'. ${ }^{73}$ Another echoed this, describing a sense of legitimacy and purpose from 'the idea of our identity: this is who we are, this is what we represent ${ }^{74}$ Here again, DPKO staff use discourse to reaffirm their exceptionalism and thus their legitimacy.

Second, staff members described legitimacy based upon their belonging to a multilateral international organisation with universal membership. Multilateralism is often associated with enhanced legitimacy, because no particular state can push its individual interests, and consensus enables decisions with input from all stakeholders, thus rendering them more representative and therefore legitimate. ${ }^{75}$ DPKO staff have strongly internalised the idea that multilateralism represents the most appropriate method of decision-making on matters of peace and security at the international level. This is of course partly due to the fact that they are a self-selected group of people who opt to work for the UN because they subscribe to the advantages of multilateralism. But they also appear to consider that the overall rightness and appropriateness of their activities derives at least partly from the fact that they are undertaken in the name of the international community and not any particular state. Accordingly, in situations where they face operational and normative dilemmas or where they feel pushed to take actions that do promote only the narrow interests of one or a few member states, they return discursively to their multilateralism, stressing the fact that they are international and impartial and that this is a source of legitimacy for them.

\footnotetext{
${ }^{66}$ Interview with UN official, Geneva, February 2017.

${ }^{67}$ Interview with former senior DPKO official, Geneva, January 2017.

${ }^{68}$ Interview with DPKO official, New York, February 2017.

${ }^{69}$ Interview with DPKO official, New York, February 2017, emphasis in original.

${ }^{70}$ Interview with former senior DPKO official, Geneva, February 2017.

${ }^{71}$ Interview with DPKO official, New York, November 2017.

${ }^{72}$ Interview with DPKO official, New York, February 2017.

${ }^{73}$ Interview with former senior UN official, Geneva, February 2017, emphasis in original.

${ }^{74}$ Interview with former senior DPKO official, New York, February 2017.

${ }^{75}$ Claude, 'Collective legitimation'.
} 
As one DPKO staff member noted, 'the legitimacy of peacekeeping traditionally and its doctrines and concepts ... stems from being the voice of the global community, the perception that it brings with it a certain impartial external voice of a global community. ${ }^{76}$ Another asserted that, 'there is a culture particularly among ... the international UN staff who make this a career that they are not reflecting a perspective of a particular country'. ${ }^{77}$ Indeed, the practice of peacekeeping, because it entails intervention, imposition, and involvement in a variety of domestic processes normally off-limits to outsiders, runs counter to norms relating to sovereignty, self-determination, and non-interference that are enshrined in the organisation's Charter. Staff thus feel much more comfortable undertaking interventions that, officially at least, have the backing of the entire international community of states because they are seen to minimise the violation of those norms. ${ }^{78}$ As a result, they utilise discourse that underscores the multilateral nature of their work, as a way of convincing themselves of their own legitimacy, even where they are, in fact, forced to violate those norms. One noted that peacekeeping operations authorised by the UN, in contrast to bilateral arrangements or ad hoc coalitions, 'give you a level of legitimacy that nobody else can claim and it's very interesting how often we come back to that as a source of strength, not weakness'. ${ }^{79}$ In this way, not only do DPKO staff derive legitimacy for peacekeeping activities through the UN's universal character, but they also maintain a very strong sense of identity as international civil servants and expressed a belief that being representatives of the international community is exceptional and inherently legitimate. ${ }^{80}$

A third source of self-legitimacy is the specialised nature of the work that DPKO does. As mentioned, DPKO staff regard themselves as experts with specialist training and experience who are 'highly motivated and skilled in pursuing their work in an effective manner'. ${ }^{81}$ Accordingly, they use discourse that reiterates this self-perception of being unique 'experts in their fields'. ${ }^{82}$ One described UN peacekeeping as 'the body of 70 years' worth of experience and 70 odd missions ... that we've directed'. ${ }^{83}$ And while that expertise is sometimes blocked by member states, DPKO staff derive an enormous amount of self-legitimacy where it is not. As one official put it, 'the UN's ability to influence [the policy making process] is all about legitimacy. ${ }^{84}$ Several others described peacekeeping as a vocation, remarking that 'being an international civil servant ... gives you a sense of purpose, it's quite inspiring. ${ }^{85}$ Discursively reiterating their specialised skills and unique professional profiles thus exceptionalises DPKO staff by enabling them to view themselves as special, superior, and thus particularly legitimate, regardless of any conflicting obligations they face. ${ }^{86}$

Fourth, in a bid to counter the loss of internal legitimacy associated with perceived failure or weak performance, staff simplify or redefine the criteria for success to entail not concrete outputs but instead advocacy, participation, and resolve. One stressed that for peacekeeping staff, success means being 'witness to [and] advocates for' peace, security, and human rights. ${ }^{87}$ Legitimacy thus derives not from concrete outcomes, but from 'advocacy on behalf of normative standards ... the

\footnotetext{
${ }^{76}$ Interview with DPKO official, New York, February 2017.

${ }^{77}$ Interview with DPKO official, New York, February 2017.

${ }^{78}$ Interview with DPKO official, New York, February 2017.

${ }^{79}$ Interview with former senior DPKO official, Geneva, January 2017, emphasis added.

${ }^{80}$ Interview with UN officials, New York, February 2017.

${ }^{81}$ Winckler, 'Exceeding limitations', p. 43.

${ }^{82}$ Allen and Yuen, 'Politics of peacekeeping', p. 623.

${ }^{83}$ Interview with DPKO official, New York, November 2017.

${ }^{84}$ Interview with DPKO official, New York, February 2017, emphasis in original.

${ }^{85}$ Interview with DPKO official, New York, February 2017.

${ }^{86}$ See Robert P. Gephart, Cagri Topal, and Zhen Zhang, 'Future-oriented sensemaking: Temporalities and institutional legitimation', in Tor Hernes and Sally Maitlis (eds), Process, Sensemaking, and Organizing (Oxford: Oxford University Press, 2010), pp. 275-312 (p. 281).

${ }^{87}$ Interview with DPKO official, New York, February 2017.
} 
advocacy of just staying there and being seen to accompany a people even in their worst days' ${ }^{88}$ Basing legitimacy on representing and advocating for certain normative standards, of course, puts UN staff above reproach, even where peacekeeping is not delivering tangible outcomes, because the normative standards of the UN are perceived by staff to be unassailable. As one remarked, 'we have to come up with a narrative ... [in which] you need to be positive' and tell 'successful stories' ${ }^{89}$ Another asserted that success entails 'preventing the absolute worst happening', ${ }^{90}$ and another declared, 'I know we are better off with peacekeeping than not. A bad peace agreement is often better than none at all. It may not be perfect, but it's better than nothing. ${ }^{, 91}$

Here, the bar for success is set extremely low and success is linked to only the most vague and most minimal of criteria, focusing much more on good intentions and inputs than concrete outputs. As one senior staff member put it, the difficult choices and imperfect decisions the UN is compelled to take matter less 'if your heart is in the right place - if you're really trying to help nations affected by conflict'. ${ }^{2}$ However, by defining success in terms of advocacy, accompaniment, and intentions, staff can almost always claim success and they can therefore retain a sense of the appropriateness of their work even where they are faced with weak results or contradictory obligations. In this way, as with references to the moral correctness of the pursuit of peace, the universality of the UN's values, its multilateralism, and their own unique expertise, discourse that highlights success and - more importantly - simplifies success criteria into ones that can always be achieved helps DPKO staff to maintain a sense of their own legitimacy even in the face of contradictory normative, operational, and institutional imperatives.

\section{The paradox of discourse: Enabling peacekeeping and reducing efficiency}

While such internal discourse could be construed as inaccurate, oversimplified, and unproductive, I argue that the narratives that DPKO staff tell themselves actually serve as an enabler for action, first by reducing risk aversion and second, by generating strong professional loyalty in staff, something that was strongly supported by my empirical data. At the same time, discursive practices are time consuming and thus costly and though they may enable action, they may also render it less efficient, an effect that was also borne out in interviews. I examine these two effects in turn, demonstrating ultimately how self-legitimation has paradoxical or ambiguous effects.

Self-legitimising discourse in DPKO, even if simplifying and self-congratulatory, enables staff to continue working in the complex circumstances described above in which they face contradictory obligations, must balance their own assessments and injunctions from member states, and are beset by weak results and scandals. Indeed, the social construction of reality that occurs through discourse 'make[s] action possible' by specifying identities, appropriate action, and interests. ${ }^{93}$ Discourse can 'authorize, enable, and justify specific practices and policies' by demonstrating that they are appropriate to a particular identity. ${ }^{94}$ This enabling occurs in two ways: by reducing risk aversion and by instilling deep professional loyalty in staff.

First, the self-referential discourse that DPKO staff use on a repeated basis reduces their aversion to risk. By reassuring them that they are acting in line with what is appropriate to their institutional identity, they are more willing to take on the difficult work of peacekeeping in risky and insecure contexts and to confront the difficult dilemmas that peacekeeping involves. Indeed, as described above, DPKO staff pride themselves on going to the hardest conflicts where the chances of peacekeeping success are remote in order to 'stand by' countries and populations affected by

\footnotetext{
${ }^{88}$ Interview with DPKO official, New York, February 2017.

${ }^{89}$ Interview with UN official, Geneva, February 2017.

${ }^{90}$ Interview with DPKO official, New York, February 2017.

${ }^{91}$ Interview with senior DPKO official, New York, February 2017.

${ }^{92}$ Interview with senior DPKO official, New York, February 2017.

${ }^{93}$ Allan, Scientific Cosmology, p. 42.

${ }^{94}$ Autesserre, 'Dangerous tales', p. 207.
} 
war. As one DPKO official put it, 'life is pretty miserable in these places, so I do think there is an element of identity and legitimacy that explains why people keep working ... with very little results to show for on a daily basis and constantly having to start again. ${ }^{95}$ If staff convince themselves that their work is successful even where outputs are weak or where mission staff are involved in gross misconduct, they are more willing to stick with it. Equally, where they are persuaded that they are doing good, then they are more likely to persist where they face choices relating, for example, to human rights or support to unpalatable armed actors. In this way, the discourse that DPKO staff use internally, even if oversimplified and inaccurate, enables them, at least in part, to persist in the face of normative-operational trade-offs, the sometimes fraught relationship with member states, and poor or non-existent results and scandals. In other words, self-legitimising discourse reaffirms to staff their identity as the people who go to difficult places, a specialised elite who persevere in the face of challenges because their work is inherently moral and legitimate.

Second, DPKO's self-legitimising discourse instills a deep loyalty to the UN in staff. As mentioned, DPKO staff regard themselves as experts with specialist training and experience and their work as necessarily correct and morally unassailable. This allows them to perceive of themselves an elite that is unique in the international system, and this self-perception generates deep pride in DPKO staff. ${ }^{96}$ Indeed, most spoke of the UN in deeply loyal, even religious terms. Several called themselves 'believers' in the $\mathrm{UN}^{97}$ and one specified that he 'ha[s] faith, despite daily testing of that faith'.$^{98}$ Another characterised the disposition among staff as 'a cult of devotion', 99 and one official declared adamantly, 'this is a religious organization for God's sake ... and we should be venerating Saint Dag [Hammarskjöld] the Martyr and Saint Ralph [Bunche] and Saint Margaret [Anstee]'. ${ }^{100}$ This deep pride and loyalty to the organisation persists even in the face of the dilemmas and trade-offs entailed by the UN's multidimensional identity and it is made possible by the self-legitimising discourse that DPKO staff tell themselves. In this way, the discursive insistence on their own exceptionalism and on belonging to a morally irreproachable organisation prevents DPKO staff from simply abandoning their work when faced with complexity and contradiction.

At the same time, while 'talk' in DPKO may enable action, it may also render that action less efficient. There are two reasons for this: the costliness of discursive self-legitimation practices and the resistance to self-evaluation that they give rise to. First, crafting and telling narratives of cohesion and appropriateness is time-consuming and thus costly. As I point out in an earlier article, staff tend to tell and retell these self-referential narratives in a form of 'ongoing selflegitimation', ${ }^{101}$ and Daniel Geiger and Elena Antonacopoulou stress that success stories in organisations are 'told over and over'. ${ }^{102}$ Indeed, staff noted that they spend a significant amount of time and resources on the repetition of self-legitimising discourse; this, however, inevitably leaves less time for the action that this discourse enables.

Second, self-legitimising discourse may discourage DPKO staff from accurately assessing their own performance, thus allowing inefficient or ineffective practices to persist. As discussed, selflegitimising discourse needs to simplify away challenges, complexity, and dilemmas, underscore the moral superiority of peacekeepers, and portray actions as aligned with overarching norms and principles, much more than it needs to be accurate. However, this in turn eliminates the need for

\footnotetext{
${ }^{95}$ Interview with UN official, New York, November 2017.

${ }^{96}$ Interview with DPKO official, New York, February 2017.

${ }^{97}$ Interviews with DPKO and UN officials, Geneva, February 2017, Berlin, May 2015, New York, February and November 2017.

${ }^{98}$ Interview with DPKO official, New York, February 2017.

${ }^{99}$ Interview with former senior DPKO official, Geneva, February 2017.

${ }^{100}$ Interview with UN official, New York, February 2017.

${ }^{101}$ von Billerbeck, “"Mirror, mirror"'.

${ }^{102}$ Daniel Geiger and Elena Antonacoupoulou, 'Narratives and organizational dynamics: Exploring blind spots and organizational inertia', The Journal of Applied Behavioral Science, 4:2 (2009), pp. 411-36 (p. 432).
} 
self-reflection or self-scrutiny and may encourage overly positive self-assessments by DPKO staff. As Meyer and Rowan point out, 'inspection and evaluation can uncover events and deviations that undermine legitimacy' and self-legitimation thus tends to ignore or downplay the need for such accurate self-assessment or scrutiny. ${ }^{103}$ Indeed, staff pointed to the slow pace of reform within the UN as symptomatic of this phenomenon. ${ }^{104}$ Furthermore, even if staff do undertake self-evaluation, they often measure their performance against criteria of appropriateness and not criteria of efficiency or effectiveness. ${ }^{105}$ This is hardly surprising: if one is convinced that one's work is inherently correct, one's objectives are necessarily good, and one's position is exceptional and unique, then there is no need to engage in detailed self-reflection and self-criticism, let alone fundamentally amend one's goals and strategies.

\section{Conclusion}

Actors in the international system engage not only in exogenous legitimation aimed at convincing those subject to their authority of their legitimacy, but also endogenous legitimation aimed at convincing themselves of their own legitimacy. To do so, they use discourse to define, validate, and reaffirm their own perceptions of their own identity and demonstrate that their behaviour aligns with that identity. This can be considered an ongoing, defining, and constitutive activity undertaken by political actors.

In the case of UN peacekeeping, however, self-legitimation is complicated by the fact that the organisation has a multifaceted identity that often dictates conflicting duties and imperatives. This, in turn, makes attempts to reaffirm a cohesive identity more difficult, but also perhaps more important, as DPKO staff are uncomfortable with 'violating' different sides of their identity. UN peacekeeping staff therefore rely on discourse that reconciles or disregards clashes between their normative, operational, and institutional obligations and that reassures them that they are acting in accordance with all parts of their identity. ${ }^{106}$ This is accomplished discursively through simplification - which diminishes the trade-offs and contradictions inherent in DPKO - and exceptionalisation - which creates a special, exclusive, and moral identity for DPKO staff.

These processes of simplification and exceptionalisation in turn enable staff in DPKO to continue the work of peacekeeping despite its complexity, and in this sense their internal 'talk' should be valued and supported. At the same time, talk takes time. It can thus eat up resources and render the actions it enables less efficient. In addition, the narratives that DPKO staff use for selflegitimation may discourage accurate self-assessment, thereby permitting inefficient and ineffective practices to persist. In this regard, self-legitimation is paradoxical and ultimately, its effects may be ambiguous: there may be no action without talk, but there is also less action with talk.

This ambiguity suggests that self-legitimising discourse has two broader repercussions. First, it may be that the use of simplifying and exceptionalising discourse in DPKO engenders a more general resistance to reform by limiting what is viewed as possible by staff. As Allan notes, discourse 'delimit[s] the imaginable, knowable, sayable, and doable', and can 'render some actions ... as unthinkable or illegitimate'. ${ }^{107}$ Autesserre, similarly, points out that narratives that are repeated over time can come to be seen as 'the only conceivable ones'. ${ }^{108}$ Self-legitimising discourse may therefore not only limit the scope for meaningful self-assessment, but more broadly predispose DPKO staff against larger reforms that fundamentally challenge how peacekeeping works, which, as noted, was evident in the empirical data presented here. The slow pace of strategic

\footnotetext{
${ }^{103}$ Meyer and Rowan, 'Institutionalized organizations', p. 359.

${ }^{104}$ Interview with UN official, New York, January 2017.

${ }^{105}$ Meyer and Rowan, 'Institutionalized organizations', p. 360.

${ }^{106}$ von Billerbeck, “"Mirror, mirror"”.

${ }^{107}$ Allan, Scientific Cosmology, pp. 41, 42. See also Marc Angenot, 'Social discourse analysis: Outlines of a research project', The Yale Journal of Criticism, 17:2 (2004), p. 200.

${ }^{108}$ Autesserre, 'Dangerous tales', p. 207.
} 
change within DPKO and the tendency to tweak how peacekeeping is done only at the margins despite numerous reform attempts undertaken over three decades since the end of the Cold War is well known. ${ }^{109}$ While there are diverse reasons for these frequent failures - including, as mentioned, hierarchy and self-interest, as well as involvement by member states and others - it is likely that discursive self-legitimation exacerbates the general resistance to reform in DPKO.

Second, self-legitimation may reduce external perceptions of DPKO's legitimacy. Although UN staff tell themselves narratives about a cohesive and positive institutional identity, they do not actually resolve the contradictions they face. Indeed, while UN staff may invoke their dedication to the pursuit of peace and to multilateralism and may attempt to convince themselves that the values and objectives they pursue are universally shared and normatively correct, the fact is that they may still violate these norms and principles in the practice of peacekeeping. On the ground, real decisions need to be taken about how to sequence or prioritise actions, decisions that are, as described, often taken in a hierarchical fashion or based upon self-interest and internal competition within DPKO. While staff may use discourse in an attempt to diminish or justify these choices, discourse does not eliminate them. As a result, DPKO staff may say one thing but do another, and their words are not necessarily backed up by actions. In this way, whether or not UN staff believe their own discourse, DPKO's external legitimacy audiences are likely to perceive a gap between the rhetoric and the reality of peacekeeping, and thus may perceive DPKO as contradictory, insincere, or unreliable. Indeed, as much as DPKO may consider its discourse as indicative of social reality, such accounts will be contested by counter-discourses from other groups and actors, whose conception of the possible, the appropriate, and the legitimate differ. As a result, it is likely that the UN's internal discourse may cause external perceptions of DPKO legitimacy to suffer, even though it may successfully boost internal ones, an effect that is likely to be exacerbated by the reduced efficiency and effectiveness that self-legitimation engenders.

It is probable that these two issues extend to both other parts of the UN system as well as other international organisations. As described, organisations that have multifaceted identities and that, as a consequence, face contradictory normative, operational, and institutional obligations will use a variety of mechanisms to resolve these tensions. Alongside hierarchy or self-interest, they will also engage in self-legitimation and the creation and telling of a unified story of organisational appropriateness. We can therefore expect a range of UN entities, such as UNDP or UNICEF, and international organisations, such as the World Bank ${ }^{110}$ or NATO, ${ }^{111}$ to use discourse to simplify the dilemmas they face and portray themselves as exceptional, relevant, and legitimate. All of these organisations play both normative and operational roles and have dual institutional structures consisting of member states and a secretariat of international staff. They thus face many of the same dilemmas that DPKO staff do, in which their multiple identities dictate multiple and at times conflicting appropriate behaviours. By contrast, organisations with singular, cohesive identities, such as the World Trade Organization, can be expected to engage in far less discursive self-legitimation as there will be fewer conflicts and tensions surrounding what is considered acceptable and appropriate.

In this regard, an awareness of why and when international organisations need to selflegitimise and how they do so can help us to better understand the behaviour of these organisations and how they can be most effective. As noted, self-legitimation has been largely omitted

\footnotetext{
${ }^{109}$ The most major and well-known calls for peacekeeping reform have been the 1992 Agenda for Peace, the 2001 Brahimi Report, and the 2014 Report of the High Level Panel on Peace Operations (HIPPO). These have been accompanied by numerous smaller reform initiatives. See Arthur Boutellis, 'From HIPPO to SG Legacy: What Prospects for UN Peace Operations Reform?', Global Observatory, International Peace Institute (24 September 2015), available at: \{https://theglobalobservatory.org/2015/09/hippo-peacekeeping-peacebuilding-united-nations/\} accessed 25 February 2020.

${ }^{110}$ von Billerbeck, "Mirror, mirror"; Catherine Weaver, Hypocrisy Trap: The World Bank and the Poverty of Reform (Princeton: Princeton University Press, 2008).

${ }^{111}$ von Billerbeck, “"Mirror, mirror”".
} 
from the study of legitimacy in international organisations, and examination of the discourse used by organisations has focused on that which is directed outwards, as part of their general public relations and advertising efforts, with internal discourse written off as bureaucratic inefficiency and a waste of time. As this article has shown however, internal 'talk', despite its deleterious effects on efficiency, effectiveness, and reform, serves an enabling function and should be considered not just a fact of organisational life, but a critical part of organisational action.

Acknowledgements. This project was generously funded by the UK Economic and Social Research Council (ES/N015967/1). I am grateful to the three anonymous reviewers for their thoughtful feedback and to the numerous people who commented on and supported this project, including participants of workshops at EISA European Workshops in International Studies 2017, ISA 2019, the Folke Bernadotte Academy, and the Dag Hammarskjöld Foundation.

Sarah von Billerbeck is a Lecturer in International Relations and co-Director of the UN and Global Order Programme at the University of Reading, UK. Her research focuses on UN peacekeeping, peacebuilding, international organisations, the United Nations, and legitimacy.

Cite this article: von Billerbeck, S. 2020. No action without talk? UN peacekeeping, discourse, and institutional self-legitimation. Review of International Studies 46, 477-494. https://doi.org/10.1017/S026021052000011X 